To Be Submitted To: Cancer Research

September 00, 1992

\title{
Inhibition of Topoisomerase II Activity in Repair-Proficisnt CHO K1 Cells by 2-[(Aminopropyl)Amino]Ethanethiol (WR-1065) ${ }^{1}$
}

\section{David J. Grdina, ${ }^{2}$ Andreas Constantinou, and Naoyuki Shigematsu}

Biological and Medical Research Division [D.J.G., N.S.], Argunne National Laboratory, Argonne, Illinois 60439; Specialized Cancer Center [A.C.I, University of Chicago, Chicago, Iliinois 60612; and Department of Radiation and Cellular Oncology [D.J.G.], University of Chicago, Chicago, Illinois 60637

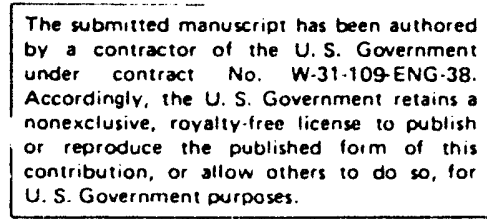

Running Title: WR-1065 Affects Topoisomerase II Activity

Key Words: Aminothiol, topoisomerase, repair, protection, radiation

${ }^{1}$ This investigation was supported by the U.S. Department of Energy under Contract No. W-31-109-ENG-38, by NIH/National Cancer Institute Grant CA-37435, and by the Center for Radiation Therapy.

${ }^{2}$ To whom reprint requests should be addressed, at Biological and Medical Research Division, Argonne National Laboratory, 9700 South Cass Avenue, BIM/202, Argonne, Illinois 60439-4833.

${ }^{3}$ The abbreviations used are: WR-2721, S-2-(3-aminopropylamino)ethylphosphorothioic acid; WR-1065, 2-I(aminopropyl)amino]ethanethiol; topo I, type I topoisomerase; topo II, type II topoisomerase; DMF, dose modifying factor; PBS, phosphate-bufferec saline; SDS, sodium dodecyl sulfate; $k D a$, kilodalton.

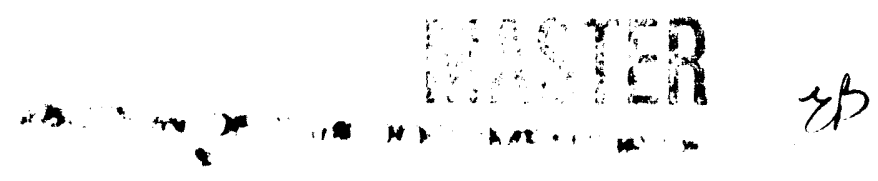




\section{ABSTRACT}

The aminothiol 2-[(aminopropyl)amino]ethanethiol (WR-1065) is the active thiol of the clinically studied radioprotective agent $S$-2-(3-aminopropylamino) ethylphosphorothioic acid (WR2721). WR-1065 is an effective radiation protector under in vitro conditions when it is administered 30 min prior to radiation exposure at a concentration of $4 \mathrm{mM}$ to repair-proficient Chinese hamster ovary $\mathrm{K} 1$ cells (i.e., a dose modiñcation factor of 1.4 ). In contrast, the DNA double-strand break, repair-deficient Chinese hamster ovary xrs-5 cell line is not protected under these conditions (i.e., a dose modification factor of i.0). Topoisomerase (topo) I and II activities and protein contents were measured in both $\mathrm{K} 1$ and xrs-5 cell lines and were found to be similar in magnitude. Neither exposure to radiation, to WR-1065, or to both affected these variables in xrs-5 cells. WR-1065 was effective, however, in reducing topo II activity by a factor of 2 in the repair-proficient $\mathrm{K} 1$ cell line. Topo II protein content, however, was not affected by these exposure conditions. One of several mechanisms of radiation protection attributed to aminothiol compounds has been their ability to affect enzymatic reactions involved in DNA synthesis, repair, and cell cycle progression. These results demonstrate a modifying effect by 2-[(aminopropyl)amino]ethanethiol on a specific nuclear enzyme (i.e., type II topoisomerase), which is involved in DNA synthesis. These results also suggest that differences do exist between the topo II enzymes isolated from the parer: repair-proficient $\mathrm{Kl}$ and the DNA double-strand break, repair-deficient xrs-5 mutant cell lines. 


\section{INTRODUCTION}

The phosphorothioate WR- $2721^{3}$ has been investigated in clinical trials as an adjuvant for use with radiation $(1,2)$ and chemotherapy $(3-5)$ to reduce normal tissue toxicity. WR-2721 and its free thiol WR-1065 have also been reported to be effective in protecting against radiation- or chemotherapy-induced mutagenesis $(6-10)$ and carcinogenesis (11-13). With respect to the antimutagenic effect, these agents significantly reduced the frequency of mutations at the hprt locus in cultured mammalian cells and rodent $T$ splenocytes, even when they were administered up to $3 \mathrm{~h}$ following exposure of cells to radiation $(6,10)$.

While the major mechanisms proposed to describe the protective effects of this class of aminothiols have focused on their well-characterized physiochemical properties (14), they have been implicated in affecting DNA synthesis and repair $(15,16)$, DNA nuclease activity (17), and cell cycle progression $(18,19)$ in mammalian cells. As early as 1967 , it was proposed that protection by aminothiol compounds is mediated via inherent cellular DNA repair processes (20). More recently it has been reported that the disulfide form of WR-1065 can enhance the topoisomerase-I-mediated unwinding of supercoiled plasmid pIBI30 DNA (21). It has been suggested that this result was not unexpected due to the similarity in chemical structure between the disulfide form of WR-1065 and the polyamine spermidine, a polyamine which has been reported to be effective in enhancing the relaxation of DNA supercoils via topoisomerase reactions $(22)$.

Using repair-proficient and -deficient mammalian cell lines, we have extended studies on the role of aminothiol-mediated effects on DNA-associated enzymes. In particular, we have characterized the effects of WR-1065 (the free thiol form of WR-2721) exposure on topo I and II activities in $\mathrm{CHO}$ repair-proficient $\mathrm{Kl}$ and repair-deficient xrs-5 cell lines (23). 


\section{MATERIALS AND METHODS}

Cells and Culture Conditions. CHO $\mathrm{K} 1$ and $x r s-5$ cell lines were maintained as stock cultures in $\alpha$-Minimal Essential Medium (Gibco) with $10 \%$ fetal calf serum (Biologos) in a humidified atmosphere containing $5 \% \mathrm{CO}_{2}$ and $95 \%$ air at $37^{\circ} \mathrm{C}$.

Drug Treatment. WR-1065 used in these studies was supplied by the Drug Synthesis and Chemistry Branch, Division of Cancer Treatment, National Cancer Institute. The working solution of WR-1065 was made up in PBS (8.1 miM Na $\mathrm{HPO}_{4}, 1.5 \mathrm{mM} \mathrm{KH}_{2} \mathrm{PO}_{4}, 0.14 \mathrm{M} \mathrm{NaCl}$, $2.6 \mathrm{mM} \mathrm{KCl}$ ) buffer at a $1 \mathrm{M}$ concentration and sterilized by filtration immediately before use. Cells were exposed to WR-1065 at a final concentration of $4 \mathrm{mM}$. At that concentration, WR-1065 is nontoxic and is maximally effective as an antimutagen and a radioprotector (6-8).

Survival Studies. Exponentially growing cultures of $\mathrm{K} 1$ and xrs- 5 cells were irradiated with 50-kVp x-rays either in the presence or absence of WR-1065 (4 mM). All experiments were performed in triplicate. Cell survival was determined by plating appropriate numbers of cells to give between 80 and 200 colonies per dish, 6 dishes per experimental point. The $\mathrm{D}_{0}$ and $95 \%$ confidence limits were determined for each survival curve using a computer-fitted, least-squares regression model. Dose modification factors were determined from survival curves by comparing the corresponding $D_{0}$ values obtained for each of the WR-1065 conditions with that of the associated radiation-only controls.

Preparation of Nuclear Extracts. Exponentially growing $\mathrm{CHO}$ K1 or xrs- 5 cells were used in all experiments. Following exposure to radiation and/or WR-1065, treated and control cells in plastic petri dishes were placed on ice, and a volume (equal to that of the culture medium) of cold solution containing $50 \mathrm{mM}$ Tris- $\mathrm{HCl}(\mathrm{pH} 7.5), 25 \mathrm{mM} \mathrm{KCl}, 2 \mathrm{mM} \mathrm{CaCl} 2,3 \mathrm{mM} \mathrm{MgCl}{ }_{2}$, and $0.25 \mathrm{M}$ sucrose was added. The cells (about $10^{8}$ ) were centrifuged and then homogenized. 
The nuclei were isolated as described by Taudou et al. (24) and extracted as described by Champoux and McConaughy (25), except that immediately after the washing of cells, a solution comprised of $1 \mathrm{mM}$ phenylmethylsulfonyl fluoride, $1 \mathrm{mM}$ ben $z$ amidine, $10 \mu \mathrm{g} / \mathrm{ml}$ soybean trypsin inhibitor, $50 \mu \mathrm{g} / \mathrm{ml}$ leupeptin, $1 \mu \mathrm{g} / \mathrm{ml}$ pepstatin, and $20 \mu \mathrm{g} / \mathrm{ml}$ aprotinin was added. The protein content of the nuclear and the cellular extracts was determined by the Bradford method (26). Glycerol was added to a final concentration of $30 \%$, and the extracts were stored at $-20{ }^{\circ} \mathrm{C}$. These preparations served as the source for topo I and II activity, as well as for topo II immunoblotting. For the unknotting assay (which detects topo II catalytic activity), serial dilutions were made such that the reaction volumes of $20 \mu$ l contained a range of 50-800 $\mu \mathrm{g}$ of nuclear extract. For the DVA relaxation assay (which detects topo I activity in the absence of ATP), reaction volumes of $20 \mu \mathrm{l}$ containing a range of $1-100 \mu \mathrm{g}$ of nuclear extract were used.

Inknotting Assay for the Determination of Topo II Activity. The enzyme sources for this assay were from serial dilutions of nuclear extracts. The substrate used was knotted DNA that had been isolated from tailless capsids of the bacteriophage P4 Virl de110, according to a modification of the methods by Liu et al. (27). Reaction mixtures of $20 \mu$ l contained $50 \mathrm{mM}$ Tris- $\mathrm{HCl}, \mathrm{pH} 8.0,100 \mathrm{mM} \mathrm{KCl}, 10 \mathrm{mM} \mathrm{MgCl}_{2}, 0.5 \mathrm{mM}$ dithiothreitol, $0.5 \mathrm{mM}$ EDTA, $40 \mu \mathrm{g} / \mathrm{ml}$ bovine serum albumin (nuclease free), and $1 \mathrm{mM}$ ATP. The reactions were started by the addition of $0.6 \mu \mathrm{g}$ of knotted DNA and terminated by the addition of $5 \mu \mathrm{l}$ of a stop solution containing 5\% SDS, $50 \mathrm{mM}$ EDTA, 25\% Ficol, and $0.05 \mathrm{mg} / \mathrm{ml}$ bromophenol blue. Samples were loaded on $0.8 \%$ agarose gels and electrophoresed at $1.5 \mathrm{~V} / \mathrm{cm}$ for $15 \mathrm{~h}$ in Tris/Borate/EDTA buffer. Gels were stained in $1 \mu \mathrm{g} / \mathrm{ml}$ ethidium bromide and then destained and photographed over a UV light source. Quantitative determination of topo II activity was determined by densitometric measurement of photographic negatives. DNA that remained knotted migrated as 
a single band to the top of the gels. One unit of unknotting activity is defined as the amount of enzyme that converts $50 \%$ of the substrate (knotted DNA) into the reaction product (unknotted DNA).

Relaxation Assay for the Determination of Topo I Activity. The substrate used in this assay was pUC8 plasmid DNA (90\% supercoiled). Each reaction volume of $20 \mu$ l contained $50 \mathrm{mM}$ Tris- $\mathrm{HCl}, \mathrm{pH} 7.4,50 \mathrm{mM} \mathrm{KCl}, 10 \mathrm{mM} \mathrm{MgCl}_{2}, 1 \mathrm{~mm}$ dithiothreitol, $0.1 \mathrm{mM}$ EDTA, and $30 \mu \mathrm{g} / \mathrm{ml}$ bovine serum albumin (nuclease free). Serial dilutions of the nuclear extracts served as the source of topo I. The reactions were started by the addition of $0.6 \mu \mathrm{g}$ of the supercoiled plasmid DNA. Following 30 -min incubations at $37^{\circ} \mathrm{C}$, the reactions were terminated by the addition of $5 \mu \mathrm{l}$ of a stop solution containing $50 \%$ sucrose, $2 \%$ SDS, $0.2 \mathrm{~m}$ EDTA, and $0.05 \%$ bromophenol blue. Samples were loaded in $0.8 \%$ gels, electrophoresed in Tris/Borate/EDTA buffer, stained, and photographed. Densitometric determination of the supercoiled form provided the means for quarititation. One unit of relaxation is defined as the amount of enzyme that converts $50 \%$ of the substrate (supercoiled DNA) into the reaction product (relaxed DNA). The omission of ATP from the assay eliminated the interference of topo II activity (28).

Immunoblotting for Determining the Topo II Protein Levels. Protein content of nuclear and cellular extracts were routinely determined (26). Extracts containing $100 \mu \mathrm{g}$ of protein were analyzed in $8 \%$ SDS polyacrylamide gels (29). Proteins were transferred electrophoretically to nitrocellulose membranes and incubated with an anti-topo-II antibody recognizing the carboxyl terminal portion of the human topo II. This polypeptide was produced by an expression plasmid p56 z11-1.8 (30). The secondary antibody was anti-rabbit igG. Detection of the bands (corresponding to the $170 \mathrm{kDa}$ form of topo II) was with the peroxidase reaction (Sigma) using 4-chloro-1-naphthol (Sigma) as the color indicator. 


\section{RESUL.TS}

WR-1065 Effects on Radiation Response of K1 and xrs-5 Cells. Treatment of K1 cells with $4 \mathrm{mM}$ of WR-1065 for $30 \mathrm{~min}$ prior to their exposure to 50-kVp x-rays resulted it. significant radiation protection, as evidenced by an increase in the survival curve parameter $D_{0}$ (i.e., a measure of the terminal slope of the curve) from $2.35 \pm 0.15 \mathrm{~Gy}$ to $3.35 \pm 0.25 \mathrm{~Gy}$ (Figure 1). The $\mathrm{D}_{0}$ values and associated $95 \%$ confidenee limits were based on a computer-fitted least-squares regression model (6). A. DMF of 1.4 was determined by taking the ratio of $\mathrm{D}_{0}$ values from the survival curves describing the response of $\mathrm{K} 1$ cells in the presence and absence of WR-1065. In contrast, no protection against raciation-induced lethality by WR-1065 was evidenced for xrs-5 cells (Figure 1 ). The $D_{0}$ values from xrs-5 survival curves, under exposure conditions with or without WR-1065, were $0.70 \pm 0.04$ and $0.70 \pm 0.09$,

$\stackrel{\text { Figure }}{\rightarrow}$ respectively.

WR-1065 Effects on the Activities of Topoisomerases I and II. Topo I and II activities were measured in untreated $\mathrm{K} 1$ and xrs-5 cells along with (a) cells exposed to WR-1065 at a concentration of $4 \mathrm{mM}$ for $30 \mathrm{~min}$, (b) cells exposed to $10 \mathrm{~Gy}$ of ionizing radiation, and (c) cells exposed to WR-1065 and ionizing radiation. Presented in Figure 2 are data from a representative experiment describing topo II (panel A) and topo I (panel B) activities in nuclear extracts of K1 cells. Described in panel A are the activities of protein extracts from untreated or WR-1065exposed $\mathrm{Kl}$ cells: $80 \mathrm{ng}$ in lane 1, $40 \mathrm{ng}$ in lane 2, $20 \mathrm{ng}$ in lane 3, $10 \mathrm{ng}$ in lane 4, and $5 \mathrm{ng}$ in lane 5.

$\stackrel{\text { Figure } 2}{\rightarrow}$

Topo I activity from nuclear extracts of $100 \mathrm{ng}$ (lan, 1), $30 \mathrm{ng}$ (lane 2), $10 \mathrm{ng}$ (lane 3), 3 ng (lane 4), $1 \mathrm{ng}$ (lane 5), and no extract (-) are described in panel B for control and WR-1065treated K1 cells. Densitometric data from four replicate experiments describing topo I and 
topo II activities from $\mathrm{K} 1$ and xrs-5 cells are summarized in Table 1 . No significant differences in topo I and II activities were observed between $\mathrm{K} 1$ and $\mathrm{xrs}-5$ cells (all groups compared to $\mathrm{K} 1$ controls, $\mathrm{p} \geq 0.05$, Student's two-tailed test). WR-1065 exhibited no effect on topo I activity in either of the two cell lines (all groups compared to $\mathrm{K} 1$ controls, $\mathrm{p} \geq 0.5$ ), nor did it affect topo II activity in xrs-5 cells ( $p \geq 0.5$, all groups compared to xrs-5 control cells). Topo II activity was, however, significantly reduced in the repair-proficient $\mathrm{Kl}$ cell line following exposure to WR-1065, as compared to the untreated control $(p=0.019)$. Following irradiation and exposure to WR-1065, topo II activity was somewhat reduced; the level of significance, however, is only suggestive ( $\mathrm{p}$ value of 0.061 ).

Since WR-1065 only affected topo II activity in the repair-proficient $\mathrm{K} 1$ cell line, topo II protein content was also determined for $\mathrm{Kl}$ cells exposed to WR-1065. Following exposure to $4 \mathrm{mM}$ of WR-1065 for $30 \mathrm{~min}$, exponentially growing $\mathrm{K} 1$ cells were lysed, and protein from nuclear extracts were electrophoresed in $8 \%$ SDS polyacrylamide gels and transferred to nitrocellulose. Blots were incubated with anti-topo-II antibody, and resulting data are presented in Figure 3. The molecular weights presented on the right ordinate are those of topo II (MW 170,000) and its proteolytic products. Prestained standards with associated molecular weights are also presented on the left side ordinate. Lanes 1-4 contain proteins from K1 cells, while lanes 5-8 contain proteins from xrs-5 cells. Untreated control cells are represented in lanes 1 and 5, WR-1065-treated cells are in lanes 2 and 6, irradiated cells are in lanes 3 and 7, and irradiated cells treated with WR-1065 are in lanes 4 and 8. A proteolytic band with a molecular weight of $150 \mathrm{kDa}$ is evident only from $\mathrm{Kl}$ cells. Densitometric measurements of protein content (150 kDa and $170 \mathrm{kDa}$ bands) are presented in Table 2 for comparison. No significant 
differences in topo II protein content were observed between any of the experimental groups $(\mathrm{p} \geq 0.30)$.

Figure $\stackrel{3}{\rightarrow} \stackrel{\text { Table }}{\rightarrow}$

Determinations of topo II protein contents in cellular lysates of $\mathrm{K} 1$ and xrs- 5 cells were also performed, and data from a representative experiment are presented in Figure 4. Under these conditions, only a single major band of topo II was observed for both $\mathrm{K} 1$ and $\mathrm{xrs}-5$ cells, suggesting that the ininor band at $150 \mathrm{kDa}$ obser ${ }^{\prime} \mathrm{d}$ for $\mathrm{K} 1$ nuclear isolates was due to enhanced proteolytic activity by this cell line. Under these conditions, the topo II protein content in $\mathrm{K} 1$ and $x r s-5$ cells was not significantly different $(p \geq 0.5)$.

\section{DISCUSSION}

Aminothiols such as WR-1065, cysteamine, or glutathione have been reported to be effective in inhibiting DNA synthesis (15), strand rejoining (21), nuclease activity (17), and cell-cycle progression (19) in mammalian cells. These effects on cellular enzymatic processes have led investigators to propose that one possible mechanism of aminothiol protection involves the enhancement of endogenous DNA repair processes (31).

Radiation protection studies performed on DNA repair-deficient organisms strongly support the suggestion that endogenous repair systems are dominant parameters which can influence the magnitude of aminothiol-mediated protection. While cysteamine was found to be an effective protective agent in wild-type $E$. coli, it was not protective in bacterial strains with defects in the rec system $(32,33)$. E. coli mutants deficient in poL I or UV endonucleases were also not amenable to protection by cysteamine (33).

X-ray repair-deficient rad mutants of Saccharomyces cerevisia were also reported to be unprotectable by cysteamine (34). Protection by cysteamine against radiation damage was 
observed only in diploid wild-iype yeast. Failure to observe protection in wild-type haploid or mutant rad diploid yeast suggests that radioprotection by this agent is mediated through a recombination-like mechanism (34). These findings have now been extended to mammalian cells by our demnnstration that the repair-deficient $x r s-5 \mathrm{CHO}$ cell line is not amenable to protection against $\mathrm{x}$-ray toxicity by the aminothiol WR-1065 (see Fig. 1, DMF = 1). In contrast, WR-1065 protected the wild type cell line, $\mathrm{K} 1$, by a factor of 1.4 .

The aminothiols exhibit close structural similarities to polyamines, which are endogenous polybasic molecules having an affinity for DNA (35). The disulfide form (designated WR-33278) of the free thiol WR-1065 has the structure $\mathrm{H}_{2} \mathrm{~N}-\left(\mathrm{CH}_{2}\right)_{3}-\mathrm{NH}-\left(\mathrm{CH}_{2}\right)_{2}-\mathrm{S}-\mathrm{S}$ $\left(\mathrm{CH}_{2}\right)_{2}-\mathrm{NH}-\left(\mathrm{CH}_{2}\right)_{3}-\mathrm{NH}_{2}$, which is very similar to the structure of spermine (i.e., $\left.\mathrm{H}_{2} \mathrm{~N}-\left(\mathrm{CH}_{2}\right)_{3}-\mathrm{NH}-\left(\mathrm{CH}_{2}\right)_{2}-\left(\mathrm{CH}_{2}\right)_{2}-\mathrm{NH}-\left(\mathrm{CH}_{2}\right)_{3}-\mathrm{NH}_{2}\right)$. It has been reported that $\mathrm{WK}-2721$ and its metabolites WR-1065 and WR-33278 can act as effective substrates and compete with polyamines for uptake into rat lung slices via well characterized polyamine transport processes (36). These compounds are also effective substrates for polyamine oxidase activity (37). Both classes of agents can interact directly with and bind to DNA $(38,39)$.

Interest in assessing the effect(s) of the aminothiol WR-1065 on enzymatic activities in repair-proficient and -deficient cells was prompted in part by these considerations. The focus of this study was limited to an investigation of topo I and II because these enzymes are known to be important in DNA synthesis $(40,41)$, and work with the polyamine spermire has been observed to enhance the formation of a stable nonconvalent complex between mammalian topo II and DNA (42). In contrast to an earlier report in which a cell-free system was used to demonstrate that the disulfide form (WR-33278) of WR-1065 was effective in stimulating the 
eukaryotic topo! unwinding of negatively supercoiled DNA (21), we were unable to observe any effect of WR-1065 at a concentration of $4 \mathrm{mM}$ on topo I activity in either $\mathrm{K} 1$ or xrs- 5 cells.

In agreement with an earlier report (43), no differences in topo II activity were observed between control (untreated) $\mathrm{K} 1$ and xrs 5 cells. Likewise, nu difference in topo II levels were measured either in nuclear or rapid cellular lysates of $\mathrm{K} 1$ and xrs-5 cells (see Figs. 3 and 4). When nuclear lysates were used to measure topo II content, a $150-\mathrm{kDa}$ band was observed only for $\mathrm{K} 1$ cells. The absence of this band in $\mathrm{xrs}-5$ derived nuclear lysates suggests a greater degree of proteolytic activity in $\mathrm{K} 1$ as compared to xrs-5 cells. The use of rapid cellular lysates demonstrated the presence of only one topo II band at $170 \mathrm{kDa}$ for both cell lines (see Fig. 4).

Topo I and II activities were unaffected in both $\mathrm{K} 1$ and xrs-5 cell lines following exposure to ionizing radiation. However, WR-1065 was effective in inhibiting topo II activity, but only in $\mathrm{Kl}$ cells. The implications of this phenomenon are at present unclear. The ability of a relatively high concentration (i.e., $4 \mathrm{mM}$ ) of WR-1065, which is required for maximal radiation protection, to inhibit topo II activity in $\mathrm{K} 1$ but not $\mathrm{xrs}-5$, suggests there are differences between the cell lines with respect to their topo II systems. If WR-1065 or its disulfide are behaving similar to a polyamine such as spermine, these results might suggest subtle differences in enzyme structure or substrate affinity of topo II enzymes isolated from these two cell lines. The suggestion that radiation protection by aminothiols is facilitated via endogenous cellular repair system (32-34), more specifically recombination-related repair processes (32-34), is consistent with the finding that WR-1065 can affect the activity of an enzyme involved in DNA topology such as topo II. Implications of the failure of WR-1065 exposure to protect or affect topo II activity in xrs-5 cells is at present unclear. However, these findings extend earlier observations 
(32-34) that radiation protection by aminothiols is facilitated by the endogenous repair capacity of cells and that topo II is a nuclear enzyme which is affected by WR-1065.

\section{ACKNOWLEDGMENTS}

The authors thank P. Dale for her technical assistance. We also thank Dr. B. Carnes for his assistance in data analysis and statistics and J. Lear for help in the preparation of this manuscript. 


\section{REFERENCES}

1. Kligerman, M. M., Turrisi, A. T., Urtasun, R. C., Norfleet, A. L., Phillips, T. L., Barkley, T., and Rubin, P. Final report on Phase I trial of WR-2721 before protracted fractionated radiation therapy. Int. J. Radiat. Oncol. Biol. Phys., 14: 1119-1122, 1988.

2. Glover, D., Fox, K. R., Weiler, C., Kligerman, M. M., Turrisi, A., and Glick, J. H. Clinical trials of WR-2721 prior to alkylating agent chemotherapy and radiotherapy. Pharmacol. Ther., 39: 3-7, 1988.

3. Woolles, P. E. V., III, Ayoob, M. J., Smith, F. P., and Dritschilo, A. Clinical trial of the effect of S-2-(3-aminopropylaminn) ethylphosphorothioic acid (WR-2721) (NSC296961) on the toxicity of cyclophosphamide. J. Clin. Oncol., 1: 198-203, 1983.

4. Glover, D., Glick, H. H., Weiler, C., Hurowitz, '3., and Kligerman, M. M. WR-2721 protects against the hematologic toxicity of cyclophosphamide: a controlled Phase II trial. J. Clin. Oncol., 4: 584-588, 1986.

5. Glover, D., Glick, J. H., Weiler, C., Fox, K., Turrisi, A., and Kligerman, M. M. Phase I/II trials of R and cis-piatinum. Int. J. Radiat. Oncol. Biol. Phys., 12: 1509-1512, 1986.

6. Grdina, D. J., Nagy, B., Hill, C. K., Wells, R. L., and Peraino, C. The radioprotector WR-1065 reduces radiation-induced mutations at the hypoxanthine-guanine phosphoribosyl transferase locus in V79 cells. Carcinogenesis, 6: 929-931, 1985.

7. Nagy, B., Dale, P. J., and Grdina, D. J. Protection against cis-diamminedichloroplatinum cytotoxicity and mutagenicity in V79 cells by 2-[(aminopropyl)amino]ethanethiol.

Cancer Res., 46: 1132-1135, 1986. 
8. Nagy, B., and Grdina, D. J. Protective effects of 2-[(aminopropyl)amino]ethanethiol against bleomycin and nitrogen mustard-induced mutagenicity in V79 cells. Int. J. Radiat. Oncol. Biol. Phys., 12: 1475-1478, 1986.

9. Kataoka, Y., Basic, I., Perrin, J., and Grdina, D. J. Antimutagenic effects of the radioprotector WR-2721 against fission-spectrum neutrons and ${ }^{60} \mathrm{Co} \gamma$-rays in mice. Int. J. Radiat. Biol., 61: 387-392, 1992.

10. Grdina, D. J., Kataoka, Y., Basic, I., and Perrin, J. The radioprotector WR-27'21 reduces neutron-induced mutations at the hypoxanthine-guanine phosphoribosyl transferase locus in mouse splenocytes when administered prior to or following irradiation.

Carcinogenesis, 13: 811-814, 1992.

11. Milas, L., Hunter, N., Stephens, C. L., and Peters, L. J. Inhibition of radiation carcinogenesis by S-2-(3-aminopropylamino)ethylphosphorothioic acid. Cancer Res., 44 : 5567-5569, 1984.

12. Grdina, D. J., Carnes, B. A., Grahn D., and Sigdestad, C. P. Protection against late effects of radiation by S-2-(3-aminopropylamino)ethylphosphorothioic acid. Cancer Res., 51: 4125-4130, 1991 .

13. Carnes, B. A., anc' Grdina, D. J. In vivo protection by the aminothiol WR-2721 against neutron-induced carcinogenesis. Int. J. Radiat. Biol., 61: 567-576, 1992.

14. Fahey, R. C. Protection by thiols. Pharmacol. Ther., 39: 101-108, 1988.

15. LaSalle, M., and Billen, D. Inhibition of DNA synthesis in murine bone marrow cells by AET and cysteamine. Ann. New York Acad. Sci., 114: 622-628, 1964. 
16. Grdina, D. J., and Nagy, B. The effect of 2-[(aminopropyl)amino]ethanethiol (WR-1065) on radiation-induced DNA damage and repair and cell progression in V79 cells.

Br. J. Cancer, 54: 933-941, 1986.

17. Grdina, D. J., Sigdestad, C. P., Dale, P. J., and Perrin, J. M. The effect of 2-[(aminopropyl)amino]ethanethiol on fission-neutron-induced DNA damage and repair. Br. J. Cancer, 59: 17-21, 1989.

18. Chatterjee, A., and Jacob-Raman, M. Modifying effect of reduced glutathione and x-rayinduced chromosome aberration and cell-cycle delay in mutagenic lymphocytc:s $\mathrm{n}$ vitro. Mutat. Res., 175: 73-82, 1986.

19. Sigdestad, C. P., Guilford, W., Perrin, J., and Grdina, D. J. Cell cycle redistribution of cultured cells after treatment with chemical radiation protectors. Cell Tissue Kinet., 21: 193-200, 1988.

20. Brown, P.E. Mechanism of action of aminothiol radioprotectors. Nature, 213: 363-364, 1967.

21. Holwitt, E. A., Koda, E., and Swenberg, C. E. Enhancement of topoisomerase Imediated unwinding of supercoiled DNA by the radioprotector WR-33278. Radiat. Res., 124: $107-109,1990$.

22. Srivenugopal, K. S., and Morris, D. R. Differential modulation by spermidine of reactions catalyzed by type I prokaryotic and eukaryotic topoisomerases. Biochemistry, 24: 4766-4771, 1985.

23. Jeggo, P. A., and Kemp, L. M. X-ray sensitive mutants of Chinese hamster ovary cell line: isolation and cross-sensitivity to other DNA-damaging agents. Mutat. Res., 112: $313-327,1983$. 
24. Tandou, G., Mirambeau, G., Lavenot, C., Garabedian, A., Vermeersch, J., and Duguet, M. DNA topoisomerase activities in concanavalin A-stimulated lymphocytes. FEBS Lett., 176: 431-435, 1984.

25. Champoux, J. J., and McConaughy, B. Purification and characterization of the DNA untwisting enzyme from rat liver. Biochemistry, 15: 4638-4642, 1976.

26. Bradford, M. M. A rapid and sensitive method for the quantitation of microgram quantities of protein utilizing the principle of protein-dye binding. Analyt. Biochem., 72: $248-254,1976$

27. Liu, L. F., Davis, J. L., and Calendar, R. Novel topologically knotted DNA from bacteriophage P4 capsids: studies with DNA topoisomerases. Nucleic Acids Res., 9: $3979-3989,1981$.

28. Potmesil, M., Hsiang, Y-H., Liu, L. F., Bank, B., Grossberg, H., Kirschenbaum, S., Forlenzar, T. J., Penziner, A., Kanganis, D., Knowies, D., Traganos, F., and Silber, R. Resistance of human leukemic and normal lymphocytes to drug-induced DNA cleavage and low levels of DNA topoisomerase II. Cancer Res., 48: 3537-3543, 1988.

29. Laemmli, U. K. Cleavage of structural proteins during the assembly of the head of bacteriophage T4. Nature, 227: 680-685, 1970.

30. Hwang, J., Shyy, S., Chen, A. Y., Juan, C. C., and Whang-Peng, J. Studies of topoisomerase-specific antitumor drugs in human lymphocytes using rabbit antisera against recombinant human topoisomerase II polypeptide. Cancer Res., 49: 958-962, 1989. 
31. Riklis, E., Iol, R., Green, M., Prager, A., Marko, R., and Mintsberg, M. Inı reased radioprotection attained by DNA repair enhancement. Pharmacol. Ther., 39: 311-322, 1988.

32. Hulsewede, J. W., and Schulte-Frohlinde, D. Radiation protection of E. Coli strains by cysteamine in the presence of oxygen. Int. J. Radiat. Biol., 50: 861-869, 1986.

33. Korystov, Y. N., and Vexler, F. B. Mechanisms of the radioprotective effect of cysteamine in Escherichia coli. Radiat. Res. 114: 550-555, 1988.

34. Petin, V. G., and Matrenina, V. L. Radioprotecting action of chemical compounds in $\gamma$-irradiated yeast celis of various genotypes. Mol. Gen. Genet., 183: 152-157, 1981.

35. Held, K. D., and Awad, S. Effects of polyamines and thiols on the radiation sensitivity of bacterial transforming DNA. Int. J. Radiat. Biol., 59: 699-710, 1991.

36. Wyatt, I., Moore, R. B., and Smith, L. L. Competition for polyamine uptake into rat lung slices by WR2721 and analogues. Int. J. Radiat. Biol., 55: 463-472, 1989.

37. Gaugas, J. M. Possible association of radioprotective and chemoprotective aminophosphorothioate drug activity with polyamine oxidase susceptibility. J. Nat. Cancer Inst., 69: 329-332, 1982.

38. Zheng, S., Newton, G. L., Gonick, G., Fahey, R. C., and Ward, J. F. Radioprotection of DNA by thiols: relationship between net change on a thiol and its ability to protect DNA. Radiat. Res., 114: 11-27, 1988.

39. Vertino, P. M., Bergeron, R. J., Cavanaugh, P. F., and Porter, C. W. Structural determinants of spermidine interactions. Biopolymers, 26: 691-703, 1987. 
40. Hickson, I. D., Davies, S. L., Davies, S. M., and Robson, C. N. DNA repair in radiation-sensitive mutants of mammalian cells: possible involvement of DNA topoisomerases. Int. J. Radiat. Biol., 58: 561-568, 1990.

41. Smith, P. J. DNA topoisomerases and radiation responses. Int. J. Radiat. Biol., 58: $553-559,1990$.

42. Pommier, Y., Kerrigan, D., and Kohn, K. Topological complexes between DNA and topoisomerase II and effects of polyamines. Biochemistry, 28: 995-1002, 1989.

43. Warters, R. L., Lyons, B. W., Li, T. M., and Chen, D. J. Topoisomerase II activity in a DNA double-strand break repair deficient Chinese hamster ovary cell line. Mutat. Res., 254: $167-174,1991$. 
Table 1 The effects of WRI065 and radiation on the activities of topo I and II in repair-proficient $\mathrm{KI}$ and double-strand-break-deficient xrs-5 $\mathrm{CHO}$ cell lines, as determined by DNA relaxation and unknotting assays, respectively. ${ }^{a}$

\begin{tabular}{ccccc}
\hline $\begin{array}{c}\text { Cell } \\
\text { Type }\end{array}$ & WR-1065 & $\gamma$-ray & $\begin{array}{c}\text { Topo I } \\
\text { (Units/ } \mu \text { g protein) }\end{array}$ \\
\hline K1 & - & - & $112 \pm 20$ & $59 \pm 14$ \\
K1 & + & - & $97 \pm 28$ & $26 \pm 3^{\mathrm{c}}$ \\
$\mathrm{K} 1$ & - & + & $92 \pm 22$ & $53 \pm 28$ \\
$\mathrm{~K} 1$ & + & + & $96 \pm 28$ & $36 \pm 13^{\mathrm{d}}$ \\
$\mathrm{xrs}-5$ & - & - & $84 \pm 16$ & $53 \pm 9$ \\
$\mathrm{xrs}-5$ & + & - & $82 \pm 20$ & $48 \pm 5$ \\
$\mathrm{xrs}-5$ & - & + & $82 \pm 22$ & $49 \pm 10$ \\
$\mathrm{xrs}-5$ & + & + & $81 \pm 24$ & $47 \pm 4$ \\
\hline
\end{tabular}

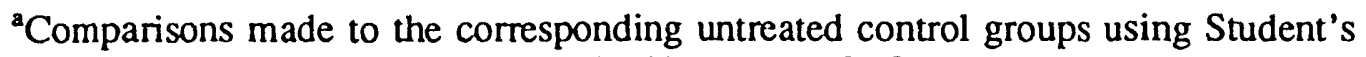
2-tailed $T$ test. Comparisons not significant, $p \geq 0.386$, except as noted.

${ }^{b}$ Mean \pm S.D. of four experiments.

${ }^{c}$ Significant difference at $\mathrm{p}=0.019$.

${ }^{d}$ Suggestive difference at $\mathrm{p}=0.061$. 
Table 2 The effects of WRIO65 and radiation on the protein levels of topo II in repair-proficient $K 1$ and double-strand-break-deficient xrs-5 CHO cell lines, as determined by immunoblotting using an anti-topo II specific antibody. ${ }^{a}$

\begin{tabular}{cccc}
\hline $\begin{array}{c}\text { Cell } \\
\text { Type }\end{array}$ & WR-1065 & -ray & $100 \times$ Area $^{\mathrm{b}}$ \\
\hline $\mathrm{K} 1$ & - & - & $167 \pm 55$ \\
$\mathrm{~K} 1$ & + & - & $179 \pm 49$ \\
$\mathrm{~K} 1$ & - & + & $219 \pm 21$ \\
$\mathrm{~K} 1$ & + & + & $163 \pm 39$ \\
$\mathrm{xrs}-5$ & - & - & $162 \pm 35$ \\
$\mathrm{xrs}-5$ & + & - & $230 \pm 35$ \\
$\mathrm{xrs}-5$ & - & + & $171 \pm 28$ \\
$\mathrm{xrs}-5$ & + & + & $170 \pm 30$ \\
\hline
\end{tabular}

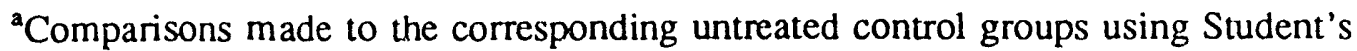
2-tailed $\mathrm{T}$ test. All comparisons not significant, $\mathrm{p} \geq 0.300$.

${ }^{b}$ Mean \pm S.D. of at least three experiments. 


\section{FIGURE LEGENDS}

Fig. 1. Survival curves for repair-proficient $\mathrm{K} 1$ and repair-deficient xrs-5 cell lines irradiated with $50-\mathrm{kVp}$ x-rays. Cells were either treated with $4 \mathrm{mM}$ of WR-1065 (E) or untreated (O). Experimental points represent the mean of three experiments; error bars represent the standard error of the mean. Survival curve parameters were determined by using a computerfitted least-squares regression model.

Figure 2. Topo II (panel A) and topo I (panel B) activity in nuclear extracts from untreated and WR-1065-treated K1 cells. Nuclear extracts containing the following amounts of protein were assayed for topo-II-mediated unknotting and topo-I-mediated relaxing activities, as described in Methods: panel A, lane 1, $80 \mathrm{ng}$; lane 2, $40 \mathrm{ng}$; lane 3, $20 \mathrm{ng}$; lane 4, $10 \mathrm{ng}$; lane 5, $5 \mathrm{ng}$; panel B, lane 1, $100 \mathrm{ng}$; lane 2, $30 \mathrm{ng}$; lane 3, $10 \mathrm{ng}$; lane 4, $3 \mathrm{ng}$; lane 5, $1 \mathrm{ng}$; $(-)$, no nuclear extract. This is a representative experiment. Data from four such experiments were used to determine the mean activities.

Fig. 3. Immunoblot analysis of topo II levels in nuclear extracts from untreated and WR-1065-treated K1 and xrs-5 cells. Logarithmically growing cells were washed twice by centrifugation at $1000 \times g$ for $5 \mathrm{~min}$ in PBS-containing protease inhibitors and extracts. Nuclear proteins were subjected to gel electrophoresis through an $8 \%$ SDS-polyacrylamide gel and transferred to nitrocellulose. Blots were incubated with anti-topo II antibody. The molecular weights shown on the right ordinate are those of topo II (MW 170,000) and its proteolytic products. Prestained standards with their molecular weights in thousands are shown on the left ordinate. Lanes 1-4, K1 cells; lanes 5-8, xrs-5 cells; untreated cells, lanes 1 and 5; WR-1065treated but unirradiated cells, lanes 2 and 6; irradiated and treated with WR-1065, lanes 4 and 7. 
Fig. 4. Immunoblot analysis of topo II levels in rapidly lysed cells. Conditions were similar to those described in Figure 3 with the exception that cells were lysed in electrophoresis sample buffer containing $2 \%$ SDS by boiling for 2 min. K1 (lane 1) and xrs-5 (lane 2) cell lysates. 

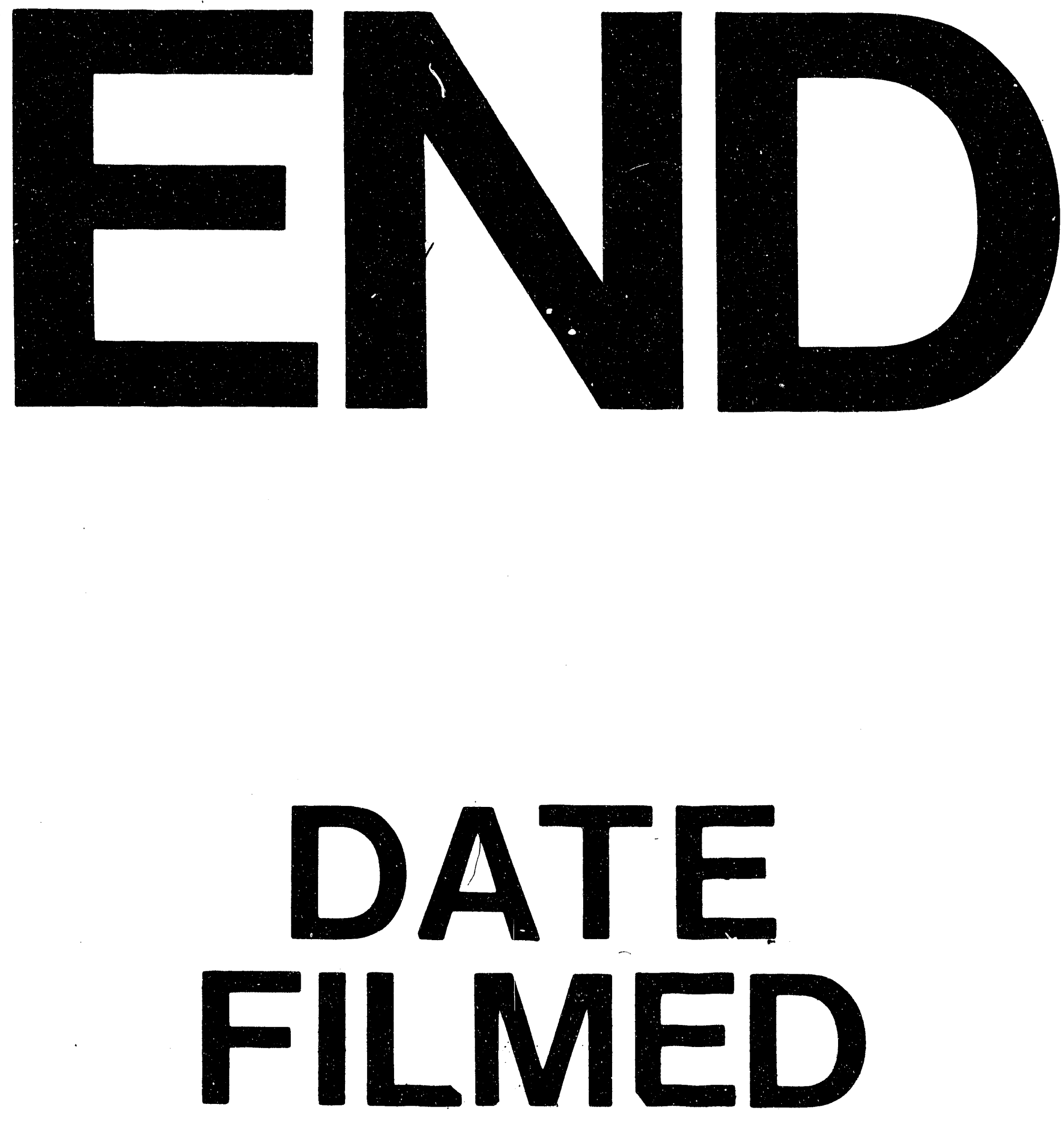

1

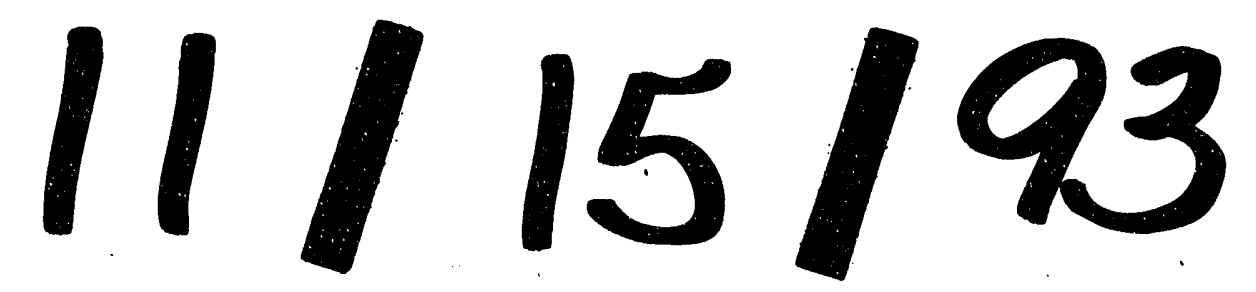


